\title{
Socio-political and ecological stresses on traditional pastoral systems: A review
}

\author{
MUHAMMAD Khurshid ${ }^{1}$, MOHAMMAD Nafees ${ }^{2}$, ABDULLAH Khan ${ }^{1}$, \\ MEHMET Somuncu ${ }^{3}$, ASHFAQ Ahmad Khan ${ }^{4}$, WAJID Rashid ${ }^{5}$ \\ 1. Department of Environmental Sciences, The University of Haripur, Khyber Pakhtunkhwa 22620, Pakistan; \\ 2. Department of Environmental Sciences, University of Peshawar, Peshawar 25000, Pakistan; \\ 3. Department of Geography, Ankara University, Sihhiye 06100, Ankara, Turkey; \\ 4. Department of Geography, Karabuk University, Karabuk 78000, Turkey; \\ 5. Department of Environmental Sciences, The University of Swat, Swat 19130, Pakistan
}

\begin{abstract}
Pastoralism is a viable socio-economic system-shaped by landless and agro-pastoral communities in many pastoral regions of the world. This system is mainly based on seasonal migration of pastoralists and their livestock herds between upland and lowland pastures. Traditionally pastoral activities make significant contributions to mountain livelihood subsistence, regional economies and environmental sustainability. However, the pastoralist's lifestyle and their economies are increasingly confronted to various socio-political, economic and ecological stresses from the last few decades. Extensive literature reviewed on this subject with the aim to explore the current emerging challenges faced by pastoral communities in different pastoral regions. It has been revealed from literature that the prevalent socio-political and economic stress on pastoralism caused by modernization, insecure land tenure, integration of market economy, civil insecurities and pastoralist's exclusion in states policies while ecological stress on pastoral activities emerged with increasing focus on nature conservation in pastoral regions and climate change induced hazards and disasters. As a consequence of these challenges, pastoral households are abandoning livestock herding-as a traditional way of life and are in continuous transition to transform their pastoral practices and institutions. Thus, the attention and consultation of key stakeholders are needed toward pastoral resource development that improve and sustain traditional pastoral practices in a socio-politically and ecologically stressed environment of the world.
\end{abstract}

Keywords: pastoralism; marginalization; pastoral system; pastures; livestock; pastoralists

\section{Introduction}

Pastoralism is a form of agriculture production system based on livestock rearing and continuous livestock mobility between upland-lowland pastures (Kreutzmann, 2012). This traditional livelihood system is adopted and shaped by pastoralists in which they are deriving more than $(50 \%)$ gross-revenue from livestock and livestock related activities (Niamir,

Received: 2017-11-16 Accepted: 2018-02-17

Author: Muhammad Khurshid, Assistant Professor, E-mail: khurshed75@live.com 
1999). Pastoral land resources (rangelands/pastures) are the heterogeneous landscapescovering more than one third land surface of the earth that are mostly managed and used by these pastoral communities (Ellis and Ramankutty, 2008), where a sustainable pastoral system significantly contributes to food and water security, national economies, support resilient pastoral livelihoods and provides important ecosystem services such as biodiversity conservation, carbon sequestration and sustainable land management (Devies et al., 2014).

Pastoral livelihood is mainly characterised by socio-ecological stress, risk and uncertainties due to changing conditions of socio-political, economic and natural environment (Scoones and Graham, 1994). Traditionally, pastoralists are reducing and overcoming these vagaries through their resilience and adaptive capacities (Fernandez-Gimenez and Febre, 2006; Tache, 2008). However, last few decades have witnessed that numerous socio-economic and political factors combined with ecological-changes stressed and reduced the capabilities and adaptive livelihood measures of pastoral communities to sustain pastoralism as a way of life and sustainable a means of natural resources use (Fernandez-Gimenez and Febre, 2006; Davies and Bennett, 2007; Dong et al., 2011). The nature and magnitude of the stress on pastoral livelihoods is varying in the socio-economic conditions and the ecosystems on which the pastoralists rely for their livelihood subsistence (Davies and Bennett, 2007; Wu et al., 2014).

This paper is presenting a theoretical framework on the base of extensive literature review to examine whether pastoral systems are indeed weakened and exposed to prevalent socio-political and ecological stress. First, we presented an overview of pastoral livelihood management strategies followed by the socio-political scenario of pastoral stress in the context of modernization, insecure land tenure, civil insecurities-wars and social conflicts and unsustainable pastoral resource development. We then focused on pastoral stress in the context of environmental changes: conservation policies and climate change-induced hazards and disasters.

\section{Pastoral livelihood management strategies in the context of stresses}

Stress imposed by changing socio-economic and ecological conditions is always remained a critical constraint in meeting livestock demand and livelihood subsistence needs in pastoral systems (Sheehy et al., 2006). The need of sustainable pastoral system must continuously be balanced with forage, water availability and secure access to grazing niches in different time-frames. Mobility, flexibility and diversity are the traditional management strategies adopted by pastoral communities to reduce various types of stresses on their livelihoods (Fernandez-Gimenez and Febre, 2006: Sheehy et al., 2006). However, the pastoral institutions and traditional management strategies are weakened due to emerging socio-economic, political and ecological changes that posed threats to sustainability of pastoral resources and livelihoods.

Pastoral livelihood management strategies have been developed over centuries in response to different environmental and socio-economic settings (Markakis, 2004; Desta et al., 2008). Key pastoral livelihood strategies are comprised of pastoralist's capabilities, assets (resources, stores), flexibility, adaptation, diversification and open mobility. These are enabling pastoralists to make the most efficient use of scarce natural resources in arid and 


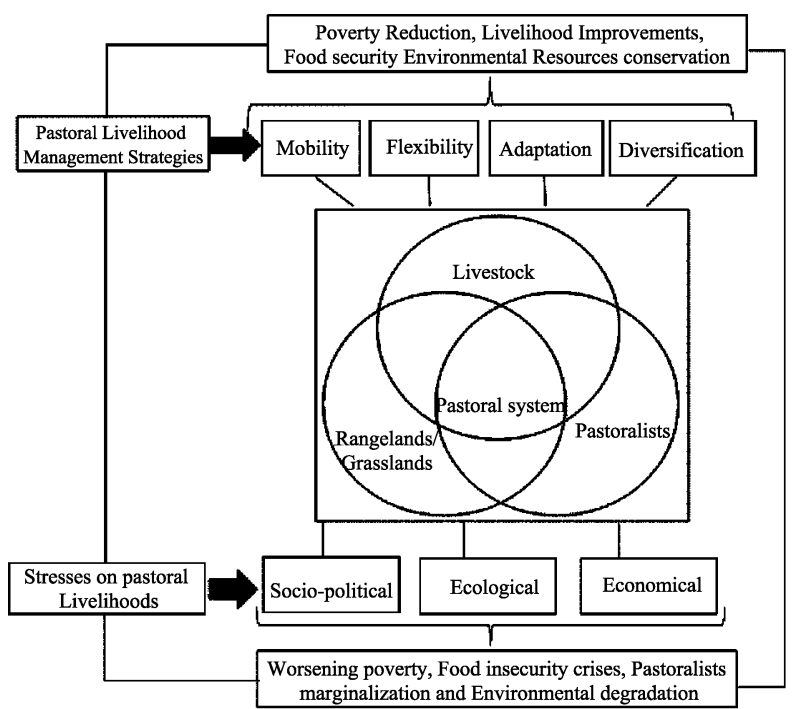

Figure 1 Pastoral livelihood system in the context of livelihood management strategies and stresses semi-arid environment that attain sustainable livelihood outcomes such as poverty alleviation, food security and improved livelihoods within the context of natural resources management (Figure 1).

The pastoral system is representing a complex human-environment interaction within the context of livestock, grasslands and pastoralists (Figure 1) that is mainly based on socio-ecological and geographical systems (Pratt et al., 1997). However, it has been increasingly recognised that the traditional pastoral strategies have been significantly stressed due to complex and multidimensional socio-ecological, economic and political processes in different pastoral regions of the world (Markakis, 2004; Kandagor, 2005). These multidimensional stresses on pastoral livelihoods are subsequently reducing the capabilities of pastoralists to resist or recover from socio-economic and political shocks that are directly or indirectly exacerbating poverty, food insecurity crises, pastoralist's marginalization and environmental degradation. Furthermore, the prevalent environmental changes- induced contingencies, shocks and stresses have also exposed pastoral communities to uncertainties, vulnerabilities and social marginalization that lead to an unbalanced human-environment system (Figure 1).

\section{Socio-political stresses on pastoral livelihoods in different perspectives}

\subsection{Modernization}

Modernization is a continuous and open ended process that enables nations to transform traditional societies, institutions and practices into modern ones. The modernization approaches started in the West and East after World War II and within the framework of early post-colonial-development decades. The interventions toward modernization initiated in many pastoral regions during pre-colonial time but they intensified during post-colonial periods (Khan, 2009; Sati, 2014). The concept of pastoralist's modernization emerged in the 20th century with the aim to settle pastoralists and adapt their traditional practices to modern expectations and perceptions (Kreutzmann, 2013). For example, modernization of pastoral systems in Iran started soon after the replacement of Qajar dynasty by Reza Khan Pahlavi regime in 1926, as pastoralists exercised relatively an autonomous life style during the Qajar dynasty. But the situation changed for pastoralists with the fall of Qajar dynasty and prevalent approaches of Reza Khan toward the country modernization and independency of the state. In this context, Reza Khan was of the opinions that the tradition lifestyle of pastoralists, their institutions and culture are the major threats to the unity of the country and barriers to the developmental programs. So they should be replaced with modern values and 
practices. For this, Reza Khan adapted forced sedentarization process of pastoralists with the aim to completely eliminate pastoralism from the country. As a consequence of these initiatives, pastoral communities lost their traditional pastures, practices, cultural norms and institutions and compelled on forced sedentarization, migration and agriculture (Tahmasebi, 2013). Kreutzmann (2013) showed that during the 20th century, numerous packages (cash and kinds) and support programmes offered to mobile pastoral communities in Central Asian region with the aim to modernize their traditional livelihood practices and institutions. This process of pastoral settlement or modernization led to disrupt the customary pastoral norms and activities and further weakened their economic viability. Similarly agriculture reform-policies considered an example of modernization in South America, where the agrarian policies designed and implemented particularly in highland areas (Dong et al., 2011). These policies replaced the traditional management system of land use with a collaborative land tenure that showed an irrational resistance to modern agrarian approaches (Swift, 2004; Westeicher et al., 2007). The implementation of modern agrarian policies sub-divided the productive pastoral areas into smaller units (Swift, 2004), that have been produced widespread socio-economic consequences for pastoralists such as poverty, social differentiation, conflict and disruption of customary pastoral land tenure system (Postigo et al., 2008).

The sedentarization of pastoralists in response to internal and external factors is mainly supported by governments, development experts, academicians and even stakeholders within the pastoral communities itself (Wu and Richard, 1999). For example, some nomadic pastoralists settled in the former Soviet Union, Iran and Israel in response to state enforced measures; others including Saami in Norway and Bedouins in Saudi Arabia in response to suitable changing economic opportunities. Similarly pastoralists are settled as sedentary households or diversifying their pastoral activities in African pastoral regions due to prolonged droughts, population pressure and political insecurities that is mainly adopted by pastoralists itself (Fratkin and Roth, 2005).

The modern approaches such as improved access to markets, natural resources, better education and health infrastructure and higher level of production/breeding technologies and the provision of alternative livelihood opportunities are considered right kind of investments for pastoral communities (Kreutzmann and Schutte, 2011). However, these approaches delivered important outcomes for the wellbeing of pastoralists in some areas, but produced worsened outcomes in the others (Kaukab, 2005).

\subsection{Insecure pastoral land tenure}

Pastoralists are often living in spatio-temporal variable environments - where as a system of land use, pastoralists on one hand need adequate and secure access to productive grazing niches and on the other hand they need to be flexible in their resource use pattern and social relationships to accommodate ecological and socio-political uncertainties. However, inappropriate management of pastoral land resources and its subsequent complexities in land tenure system are considered key factors behind marginalization of pastoral practices and ecological degradation (Fernandez-Gimenez, 2002; Nautiyal, 2003). Lack of clear property rights is reducing pastoralist's access to productive grazing niches and restricts open livestock mobility between different ecosystems. Furthermore, this land tenure ambiguity is reducing the long-term investment in land use management and other natural resource conser- 
vation that subsequently leads to environmental degradation.

Elhadary (2010) studied pastoral land tenure issues in connection with pastoral livelihood security in Eastern Sudan. Pastoralists access to grazing land mainly governed by the customary communal rules or rights though there were some shortcomings such as lack of transparencies, social understanding and gender biases. The successive governments attempted several times to control the pastoral land resources and undermine communal land tenure system. In this context, unregistered Act (1970), was such an initiative of the government in Eastern Sudan that grabbed pastoral land and reallocated to the public and other private sectors without considering the communal rights to resource utilization and access to land. As a result of this land grabbing under unregistered Act (1970), mechanized farming system expanded and caused significant implications for pastoral systems and economy. Similarly, pasture land privatization in Central Asia and Inner Mongolia of China fragmented rangeland resources into smaller units; the imposed restrictions on livestock mobility to seasonal pastures and water resources that have negatively affected both pasture conditions and livestock productivity (Coughenour et al., 2008).

In 2002, Kyrgyz Government instituted legal changes in pasture tenure laws that are leasing pastures on territorial base to individual or community groups through local administration (Undeland, 2005). However, this pasture lease system was more complicated than the previous one and had produced profound implications for pastoral livelihoods and questioned the long term sustainability of pastures. For example, the accessible areas overused wealthy and influential people excluded poor households from productive areas and limited their access to larger and remote pastures (Jones, 2003; Lerman and Sedik, 2009). In 2009, this lease system abandoned and transferred local administrative authority over pastures use to local grazing committee at community level. This changing pasture tenure system created social tension for pastoral communities particularly poor due to the dominancy of wealthy and influential herders who excluded the poor from larger pastures i.e. larger herd owners privatized remote and larger pastures while those having smaller herds lose access to these larger pastures and are compellingly overgrazed the accessible pastures (Steimann, 2011). Furthermore, pastoral land is also privatized in other Central Asian countries that has increasingly considered a key factor in pastoral livelihood vulnerability and pasture resource degradation (Peyrouse, 2009; Rowe, 2010).

\subsection{Civil insecurity: Wars and violent conflicts}

Civil insecurity is one of the most important factors contributing to social tension and stress among pastoral communities (Nori et al., 2005). The socio-political insecurity situation leads to violent conflict or wars that poses a great threat to pastoral livelihoods in terms of human and livestock loss, limited access to markets, water and pasture resources and ultimately compelled them on forced migration. Conflict in the broadest sense can be defined as "forceful interaction as a result of opposing views" (Schilling et al., 2012), particularly emerged in pastoral regions due to resource scarcity and ownership, transboundary movement between regions or countries and political instability (Shettima and Tar, 2008).

Scarcity of resources is primarily associated with social conflict within pastoral communities in Sub-Saharan African drylands (Nori et al., 2005) that is mainly caused by demographic pressure, land use changes and shrinking grazing lands for pastoralists (McCabe, 
2004). Numerous studies revealed that a number of large scale clashes occurred during the past few decades among Ethiopian pastoralists and led to severe human loss, causalities and family's displacement (Gebre, 2001; Abdullah, 2005). Among the most publicized incidents occurred are Afar-Issa (Afar and Somali region), Anuak-Nuer (Gambella), Sheikash-Ogaden (Somali region) and the Guji-Borana (Oromiya region) disputes. However, the government regularly monitor these pastoral zones through concern and inter-governmental authorities to avoid conflicts within pastoral communities (Hagmann and Mulugeta, 2008).

Dispute over land ownership is another factor contributing to conflicts and wars, especially occurred in Hindu Kush-Himalayan (HKH) region (Afghanistan, Pakistan and India), East Africa (Sudan, Somali, Kenya and Ethiopian-Somali border regions). For example, in Afghanistan, there is a long-standing social conflict over pastures ownership between Pashtun nomads and Hazara communities in highlands. This conflict is further triggered by Taliban regime in Kabul who are the direct supporters of Pashtun-nomads (Wiley, 2004; Robinett et al., 2008). Similarly, the absentee landlords evicted landless and agro-pastoralists from their upland pastures in Swat district of Khyber Pakhtunkhwa through influential rule of Taliban (Irfanullah, 2002). Similarly, a conflict over resources ownership became severe in Sudan when government mobilized an armed militant group among pastoralists in fight against opposing group with whom they are competing for access to natural resources (Young, 2012).

\subsection{Unsustainable pastoral resource development}

Some of the pastoral communities are residing in the vicinity of international or regional borderlands where they are moving through their traditional routs and often crossing regional or country borders. Such trans-boundary movement of pastoralists between different countries have greatly enhanced their pastoral activities i.e. petty trading, labour migration and seasonal exploitation of grazing resources (Nori et al., 2005). However, pastoral communities are continuously under stress and suffering in these frontier-border regions due to transitional situations of political wars, theft and social insecurity and further end-up far away from decision making institutes (Galaty et al., 1994; Leff et al., 2009).

Pastoral development is generally perceived as a social activity-aimed to improve pastoralist's access to key social and veterinary services together with pastoral institutions development for rangeland resource management (Salih, 1985; Butcher, 1994). The implementation of development policy interventions through good pastoral governance not only provides standard life opportunities for pastoralists but also endeavours to conserve the traditional socio-cultural features of the pastoral society. Furthermore, specifically livestock development projects attempt to improve the quality and quantity of livestock and their products through improved breeding strategies and marketing which are linked with better infrastructure (roads, water) improved natural resources (pastures, land) and superior-technology (education, skills) (Nyariki and Ngugi, 2002). Sustainable development in the context of pastoralism means to maintain livestock productivity in the long run, ensure pastoralists secure access to natural resources i.e., grazing and water etc, and to provide socio-political security to pastoralists. However, many developmental interventions in different pastoral regions across the world are inadequately addressing these human-capital (health, education, gender etc), social capital (institutional development) and natural capital (natural resources) 
due to the stereotype views that pastoral activity is economically irrational, environmentally un-suitable (destructive) and wasteful (Fratkin and Mearns, 2003). According to Admasu et al. (2010) and Wallner et al. (2007) such pastoral development programs are often failed because of less recognition of pastoral knowledge and interest in development process and policies. As a result these programs are negatively affecting both local inhabitants and the environment in which they live.

Pastoralists are among the most geographically, socially and politically marginalised social group, inhabiting in the regions that are mainly characterised by rough topography, extreme climatic conditions, limited accessibility and poor infrastructure development (Zinsstag et al., 2006). The main reason behind the socio-political marginalization of pastoralists is their exclusion from development process due to weak pastoral governance or pastoralist's representation in decision making institutions (Ogachi, 2011).

The research study of Wangui (2008) in Kenya revealed that during the past few decades, the developmental interventions brought significant changes in pastoral practices such as sedentarization, land use changes, new grazing system, new livestock breeds and increased child enrolment in schools. As a result of these changes family labour distribution pattern is affected and a fundamental shift observed in gender role among pastoralists in livestock production. A balanced gendered aspect of pastoral society has ignored in these developmental programs, though the effects of developmental programs on man and woman are varying, as observed in other regions also (Schroeder, 1999). A balanced gender-consideration among pastoralists is accounted as a central component to the success of pastoral development projects while un-balanced gender may lead to failure of the projects (Wangui, 2008). Similarly Rai et al. (2005) research study in the HKH region showed that foreign donors and British government have been supported particularly natural resource management projects in South Asian countries during past few decades. Case studies of forestry projects from Nepal and India showed that seasonal grazers (pastoralists) being a dis-advantaged and marginalized group excluded from the direct benefits of these initiatives and restricted their access to forest zone under participatory resource management regimes. As a result, pastoralists lost access to many productive grazing niches due to their curtailed mobility; compellingly pastoralists are now restructuring their traditional livelihood activities through off-farm employment and out-migration.

Different research studies on pastoral areas across the world revealed that sustainable pastoral resource development requires not only technical expertise but also social dimensions such as indigenous pastoral practices, pastoral institutions and socio-economic capitals. Without considering these factors in state policies and development schemes related to pastoral resource development, sustainable natural resource management will not be possible that subsequently may lead to effect on sustainability of pastoral system (Banks et al., 2003; Dong et al., 2009).

\section{Ecological and climate change induced stresses}

According to Anderson (1999), many attempts made in arid and semi-arid landscapes aimed to modernize the traditional pastoral practices through sedentarization policies and projects. Failure of these schemes led to unwanted socio-economic and ecological consequences and 
increased social tension among pastoral communities and development experts who in turn blamed pastoralists for being their conservative attitudes toward development and widespread consequences.

\subsection{Ecological consideration: a challenge for sustainable pastoralism}

Conservation-induced displacement or eviction of indigenous people-pastoralists from their land is an important issue of concern, as conservation policies are negatively affecting pastoralists in many pastoral regions of the world; compelling them to evacuate the areas allocated for conservation (Brockington and Igoe, 2006). Though pastoralism itself increasingly acknowledged and appreciated as a conservation strategy and environmentally friendly practice in the world (Nori and Gemini, 2011), this emerging debatable point the so-called dispute between conservationists and pastoralists has increasingly recognised the importance of balancing natural resource conservation with local community interest (Roe, 2008).

The enforcement of policies towards nature conservation often resulted in the establishment and creation of national parks, protected areas and game reserves aiming to conserve local biological diversity (Saberwal, 1996). However, these initiatives either minimised access of local residents/community to natural resources within the conservation site or evicted particularly pastoralists from conservation site for being their mobile status (Mattee and Shem, 2006). Conservation-oriented policies suffered pastoralists mainly due to little understanding the ecological significance of pastoralism by government stakeholders, policy makers and development planners.

The current increasing international emphasis on biodiversity conservation led to the declaration of new protected areas, sanctuaries and national parks in the rangeland areas (Nusrat, 2011), where several productive alpine pastures or rangelands converted into national parks, game reserves and world heritage sites. As a result pastoralists are evicted from their traditional pastoral habitat and pushed their herds to unproductive marginal lands, though pastoralists play a central role in nature conservation. The China-Grassland Ban Policy (GBP) initiated in 2002 aimed to restore and conserve the degraded grassland ecosystem. Initially the policy implemented in Inner Mongolia and Xinjiang and later extended to all pastoral areas in Western and Northern China. The GBP combined with other conservation policies for biodiversity reduced pastoralist's free access to diverse grazing niches and water resources. These emerging conservation efforts stressed pastoral livelihood and challenged its sustainability in the long-run (Mehta and Heinen, 2001).

As a result of current global efforts for conservation, protected areas have been expanded three-fold during last few decades and occupied $6 \%$ of the land surface of the earth. However, conservationists are not seriously considering the rights and social status of indigenous people living in the territory of protected areas or conservation sites. Though the importance of social impacts of conservation for indigenous people was recognised in the last Conference of the Parties of the Convention of Bio-diversity and World Conservation Congress of IUCN held in 2004 (Brockington et al., 2006).

\subsection{Climate change-induced hazards and disasters}

Climate change has always been remained a key challenge to human livelihood (Sewando et al., 2016). As climatic changes lead to severe natural hazards and disasters that are adversely 
affecting millions of livelihoods in the world (IPCC, 2007). Poor are more vulnerable to climate changes - among 1.3 billion poor people in the world, at least $90 \%$ of them are living in Asia and Sub-Saharan Africa, where 600 million people are extremely vulnerable to climate changes who primarily depend on livestock production for their livelihoods (Thornton et al., 2002). This climate change is affecting livestock production in term of quantity and quality of feeding resources, water availability, mobility, livestock diseases and species in the herds (Thornton et al., 2002). However, the impacts of climate change and its related hazards on livestock production systems are varying in degree and nature mainly depend on the ecosystem and pastoralists response-strategies to climatic shocks (Morton, 2007).

Climate change-induced hazards such as droughts, desertification, famine and floods have imposed significant stresses on pastoral livelihoods (Eriksson et al., 2009), as pastoralists are mainly living in more risk-prone environment i.e. high mountain-steppes, savannas and deserts (Tahmasebi et al., 2013). These ecosystems are extremely sensitive to climate changes on a global scale due to their natural exposure and geographical settings; sometimes even small change in climatic conditions may directly affect traditional nomadic people, their economy and lifestyle and the ecosystems on which they are dependent (Tahmasebi et al., 2013). Livestock mobility, changing herd structure (multi-species herds), cash saving, provision of supplementary feeding for livestock and livelihood diversification are adaptive strategies of pastoralists in response to climatic changes (Morton, 2007). However these adaptive strategies of pastoralists to climatic shocks are varying from region to region and mainly depend on their socio-economic and ecological systems (Smit and Wandel, 2006).

Climate change is increasingly changing socio-economic and ecological systems at different spatial and temporal scales in Hindu Kush-Himalayan region (Shaoliang and Sharma, 2009). Joshi et al. (2013) studied herder's perceptions toward climate changes in Hindu Kush-Himalayan region particularly in arid and semi-arid environment of Northern Pakistan. According to herder's perception, the current prevailing climate changes are directly impacting pasture resources and livestock production by altering vegetation composition and reducing forage yields. As a consequence, pastoralists have adopted migration and livelihood diversification as adaptive strategies to climate changes.

\section{Conclusions}

The dryland pastoral areas are severely affected by climatic hazards i.e. desertification, droughts and famine (Haile, 2005). The severity of these climatic hazards is continuously increasing from the last few decades and the impacts of these hazardous situations are mainly experienced by poor-inhabiting in the dryland areas who depend on natural resources such as rangelands, livestock and agriculture for their livelihoods (Hulme, 1996). The climatic events are affecting livestock health, forage availability, carrying capacity of the rangelands and agricultural production systems (Galvin et al., 2004; Mertz et al., 2009). Pastoral communities have been adapted diverse coping strategies to sustain their production systems on these marginal environment. Pastoral strategies for sustaining their production included livestock mobility according to the forage and water availability, keeping hazard-resilient species in their herds, livelihood diversification through agriculture, wage labouring and out-migration. However, there are certain constraints in these adaptive strategies 
that make pastoralists more vulnerable to climatic changes and climate-induced hazards. For example, unclear land tenure system, population growth, poverty and livestock diseases reduced the capacity of pastoralists to keep larger herds for their livelihood dependency whereas opportunities for livelihood diversification are lacking (Galvin et al., 2004).

Pastoralism is increasingly recognised as an efficient means of natural resource management and appreciated as an environmentally friendly practice both in the arid and semi-arid environment. This role of pastoralism in the provision of key ecosystem services has also been acknowledged in different multi-literal conventions such as biodiversity conventions. However, the traditional pastoral systems are continuously eroded in many pastoral regions particularly in developing world due to current socio-political and ecological challenges.

The extensive review on pastoralists livelihood marginalization showed that the current prevalent socio-political and economic stress on pastoralism caused by modernization, insecure land tenure, integration of market economy, civil insecurities and pastoralist's exclusion in states policies while ecological stress on pastoral activities emerged with increasing focus on nature conservation in pastoral regions that is further triggered by climate change induced hazards and disasters. All these factors have affected the ability of pastoralists to sustain traditional pastoral system as a way of life, culture and traditional grazing resource management.

\section{References}

Abdulahi M, 2005. The changing nature of pastoral conflicts in South-Eastern Ethiopia. In: Witsenburg W R, Pastoral Sedentarisation, Natural Resource Management, and Livelihood Diversification in Marsabit District, Northern Kenya. 2008. Lewiston: Edwin Mellen.

Admasu T E, Abule, Tessema Z K, 2010. Livestock-rangeland management practices and community perceptions towards rangeland degradation in South Omo zone of Southern Ethiopia. Livestock Research for Rural Development, 22(1): 5 .

Anderson D, 1999. Rehabilitation, resettlement and restocking: Ideology and practice in pastoralist development. The Poor Are Not Us: Poverty and Pastoralism, 240-256.

Banks T C, Richard, Li P et al., 2003. Community-based pastureland management in western China: Rationale,

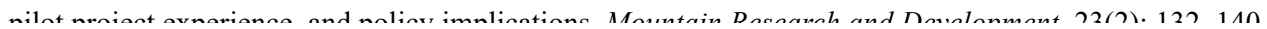

Brockington D J, Igoe J, Schmidt-Soltau K A I, 2006. Conservation, human rights, and poverty reduction. Conservation Biology, 20(1): 250-252.

Butcher C, 1994. Nomadic Pastoralism and Extension: A Review of the Literature. Overseas Development Institute: Pastoral Development Network Paper 37d.

Coughenour M, Behnke R et al., 2008. Forage distributions, range condition, and the importance of pastoral movement in Central Asia: A remote sensing study. In: Roy Behnki ed. The Socio-Economic Causes and Consequences of Desertification in Central Asia. NATO Science for Peace and Security Series-C: Environmental Security: 45-80. Netherlands: Springer.

Davies J, Bennett R, 2007. Livelihood adaptation to risk: Constraints and opportunities for pastoral development in Ethiopia's afar region. Journal of Development Studies, 43: 490-511.

Desta S, Berhanu W et al., 2008. Pastoral Drop Out Study in Selected Weredas of Borana Sone Oromia Regional State. Care International Ethiopia.

Dong S, Lassoie J et al., 2009. Institutional development for sustainable rangeland resource and ecosystem management in mountainous areas of northern Nepal. Journal of Environmental Management, 90(2): 994-1003.

Dong S, Wen L, Liu S et al., 2011. Vulnerability of worldwide pastoralism to global changes and interdisciplinary strategies for sustainable pastoralism. Ecology and Society, 16(2): 10. 
Elhadary Y A E, 2010. Challenges facing land tenure system in relation to pastoral livelihood security in Gedarif State, Eastern Sudan. Journal of Geography and Regional Planning, 3(9): 208-218.

Ellis E C, Ramankutty N, 2008. Putting people in the map: Anthropogenic biomes of the world. Frontiers in Ecology and the Environment, 6(8): 439-447.

Eriksson M, Jianchu X, Shrestha A B et al., 2009. The changing Himalayas: Impact of climate change on water resources and livelihoods in the greater Himalayas. International Centre for Integrated Mountain Development (ICIMOD).

Fernandez-Gimenez M E, 2002. Spatial and social boundaries and the paradox of pastoral land tenure: A case study from postsocialist Mongolia. Human Ecology, 30(1): 49-78.

Fernandez-Gimenez M E, Febre S L, 2006. Mobility in pastoral systems: Dynamic flux or downward trend? The International Journal of Sustainable Development and World Ecology, 13(5): 341-362.

Fratkin E, Mearns R, 2003. Sustainability and pastoral livelihoods: Lessons from East African Maasai and Mongolia. Human Organization, 62(2): 112-122.

Fratkin E, Roth E A, 2005. As Pastoralists Settle: Social, Health and Economic Consequences of Pastoral Sedentarization in Marsabit District, Kenya. New York: Kluwer Academic Publishers, pp.280.

Galaty J G, 1994. Rangeland tenure and pastoralism in Africa. In: Fratkin et al. 1994: 185-204.

Galvin K A Thornton P K, Boone R B et al., 2004. Climate variability and impacts on East African livestock herders: The Maasai of Ngorongoro Conservation Area, Tanzania. African Journal of Range and Forage Science, 21(3): 183-189.

Gebre A, 2001. Conflict management, resolution and institutions among the Karrayyu and their neighbors. In: Dietz M A M, Ahmed A G M ed. African Pastoralism: Conflict, Institutions and Government. London: Pluto Press, 81-99.

Hagmann T, Mulugeta A, 2008. Pastoral conflicts and state-building in the Ethiopian lowlands. Africa Spectrum, $19-37$.

Herrera P M, Davies J, Baena P M, 2014. Principles of pastoralist's governance and land management. In: Herrera et al. ed. The Governance of Rangelands: Collective Action for Sustainable Pastoralism. Routledge, 1-32.

Homewood K, 2006. As pastoralists settle: Social, health and economic consequences of pastoral sedentarization in Marsabit district, Kenya.

Hulme M, 1996. Recent climatic change in the world's drylands. Geophysical Research Letters, 23(1): 61-64.

IPCC (Intergovernmental Panel on Climate Change), 2007. Climate change: Impacts, adaptation and vulnerability. In: Parry M L, Canziani O F, Palutikof J P et al. eds., Contribution of Working Group II to the Fourth Assessment Report of the Intergovernmental Panel on Climate Change: Annex I. Cambridge: Cambridge University Press.

Irfanullah S, 2002. Gujars in the Pakistani Hindu Kush-Himalayas: Conflicts and dilemmas about lifestyles and forest use. Nomadic Peoples, 6: 99-109.

Jones K D, 2003. Land privatization and conflict in Central Asia: Is Kyrgyzstan a model? In: Burghart D, Sabonis-Helf T eds. In the Tracks of Tamerlane: Central Asia's Paths to the 21 st Century. Washington DC: Center for Technology and National Security Policy, 259-273.

Kandagor D R, 2005. Rethinking pastoralism and African development: A case study of the Horn of Africa. Proceedings from lecture, Egerton University, Njoro.

Kaukab S, 2005. Situation of migration and potential available to reverse the brain drain: Case from Pakistan. Public Personnel Management, 34(1): 103-112.

Khan M H, 2009. Participatory Rural Development in Pakistan. Experience of Rural Support Programmes. Karachi, Pakistan: Oxford University Press.

Kreutzmann H, 2012. Pastoral practices in transition: Animal husbandry in high Asian contexts. In: Kreutzmann ed. Pastoral Practices in High Asia. Netherlands: Springer, 1-29.

Kreutzmann H, 2013. The tragedy of responsibility in high Asia: Modernizing traditional pastoral practices and preserving modernist worldviews. Pastoralism: Research, Policy and Practice, 3(1): 1.

Kreutzmann H, Schütte S, 2011. Contested commons: Multiple insecurities of pastoralists in North-Eastern Afghanistan. Erdkunde, 99-119.

Leff J, 2009. Pastoralists at war: Violence and security in the Kenya-Sudan-Uganda border region. International 
Journal of Conflict and Violence (IJCV), 3(2): 188-203.

Lerman Z, Sedik D, 2009. Agrarian Reform in Kyrgyzstan: Achievements and the Unfinished Agenda. Policy Studies on Rural Transition No.2009 (1). Budapest, Hungary: FAO Regional Office for Europe and Central Asia.

Markakis J, 2004. Pastoralism on the Margin. London: Minority Rights Group International, 2-37.

Mattee A Z, Shem M, 2006. Ambivalence and Contradiction: A Review of the Policy Environment in Tanzania in Relation to Pastoralism. Drylands Issue Paper No.140. IIED, London, UK.

McCabe T J, 2004. Cattle Bring us to Our Enemies: Turkana Ecology, Politics, and Raiding in a Disequilibrium system. Ann Arbor: University of Michigan Press.

Mehta J N, Heinen J T, 2001. Does community-based conservation shape favorable attitudes among locals? An empirical study from Nepal. Environmental Management, 28(2): 165-177.

Mertz O, Mbow C, Reenberg A et al., 2009. Farmers' perceptions of climate change and agricultural adaptation strategies in rural Sahel. Environmental Management, 43(5): 804-816.

Morton J F, 2007. The impact of climate change on smallholder and subsistence agriculture. Proceedings of the National Academy of Sciences, 104(50): 19680-19685.

Nautiyal S, Rao K S, Rao R K et al., 2003. Transhumant pastoralism in the Nanda Devi Biosphere Reserve, India: A case study in the buffer zone. Mountain Research and Development, 23(3): 255-262.

Niamir-Fuller M, 1999. Managing mobility in African rangelands. In: MacCarthy ed. Property Rights, Risk and Livestock Development in Africa, 102-131. International Food Policy Research Institute.

Nori M, Switzer J, Crawford A, 2005. Herding on the brink: Towards a global survey of pastoral communities and conflict. An Occasional Working Paper from the IUCN Commission on Environmental, Economic and Social Policy. International Institute for Sustainable Development (IISD).

Nori S, Gemini M, 2011. The common agricultural policy vis-à-vis European pastoralists: Principles and practices. Pastoralism: Research, Policy and Practice, 1: 1-27.

Nusrat R, 2011. Marginalization of Himalayan pastoralists and exclusion from their traditional habitat: A case study of Van Gujjars in India. International Journal of Human Development and Sustainability, 4: 93-102.

Nyariki D M, Ngugi R K, 2002. A review of African pastoral production systems: Approaches to their understanding and development. Journal of Human Ecology, 13(3): 237-250.

Ogachi I O, 2011. Transforming Education and Development Policies for Pastoralist Communities in Kenya: Through the Integration of Indigenous Knowledge Systems. African Books Collective.

Peyrouse S, 2009. The Multiple Paradoxes of the Agriculture Issue in Central Asia. EUCAM Working Paper (6). Brussels, Belgium: European Union Central Asia Monitoring.

Postigo J C, Young K R, Crews K A, 2008. Change and continuity in a pastoralist community in the high Peruvian Andes. Human Ecology, 36: 535-551.

Pratt D, Le Gall F, Haan C, 1997. Investing in pastoralism sustainable natural resource use in Arid Africa and the Middle East. World Bank Technical Paper No.365.

Rai S I, CEGG, N. Kathmandu, 2005. Equity and poverty linkages in the management of commons in the Hindu Kush-Himalayas. In: Resource Constraints and Management Options in Mountain Watersheds of the Himalayas. Proceedings of a Regional Workshop, Kathmandu, Nepal, 8-9 December 2003. (pp.275-279). International Centre for Integrated Mountain Development (ICIMOD).

Robinett D, Miller D, Bedunah D, 2008. Central Afghanistan rangelands: A history of tribal rule, grazing, war, and rebuilding. Rangelands, 30: 2-12.

Roe D, 2008. The origins and evolution of the conservation-poverty debate: A review of key literature, events and policy processes. Oryx, 42(4): 491-503.

Rowe W C, 2010. Agrarian adaptations in Tajikistan: Land reform, water and law. Central Asian Survey, 29(2): 189-20.

Saberwal V K, 1996. Pastoral politics: Gaddi grazing, degradation, and biodiversity conservation in Himachal Pradesh, India. Conservation Biology, 10(3): 741-749.

Salih M A M, 1985. Pastoralists in town: Some recent trends in pastoralism in the north west of Omdurman District.

Sati V P, 2014. Towards Sustainable Livelihoods and Ecosystems in Mountain Regions. Heidelberg, Germany: 
Springer.

Schilling J, Opiyo F E, Scheffran J, 2012. Raiding pastoral livelihoods: Motives and effects of violent conflict in north-western Kenya. Pastoralism: Research, Policy and Practice, 2(1): 1.

Schroeder R A, 1999. Shady Practices: Agroforestry and Gender Politics in the Gambia. Berkeley, CA: University of California Press.

Scoones I, Graham O, 1994. New directions for pastoral development in Africa. Development in Practice, 4(3): $188-198$.

Sewando P T, Mutabazi K D, Mdoe N Y, 2016. Vulnerability of agro-pastoral farmers to climate risks in northern and central Tanzania. Development Studies Research, 3(1): 11-24.

Shaoliang Y, Sharma E, 2009. Climate change and the Hindu Kush-Himalayan Rangelands. In: ICIMOD ed. ICIMOD Publications Unit. ICIMOD Publications Unit, Kathmandu.

Sheehy D P, Miller D, Johnson D A, 2006. Transformation of traditional pastoral livestock systems on the Tibetan steppe. Science et Changements Planétaires/Sécheresse, 17(1): 142-151.

Shettima A G, Tar U A, 2008. Farmer-pastoralist conflict in West Africa: Exploring the causes and consequences. Information, Society and Justice Journal, 1(2): 163-184.

Smit B, Wandel J, 2006. Adaptation, adaptive capacity and vulnerability. Global Environmental Change, 16(3): 282-292.

Steimann B, 2011. Making a living in uncertainty: Agro-pastoral livelihoods and institutional transformations in post-socialist rural Kyrgyzstan. Human Geography Series: 26. Bishkek, Kyrgyzstan: University of Zurich.

Swift J J, 2004. The global drylands imperative: Pastoralism and mobility in the drylands. United Nations Development Programme Drylands Development Centre, Nairobi, Kenya.

Tache B, 2008. Pastoralism under stress: Resources, institutions and poverty among the Borana Oromo in southern Ethiopia. Norwegian University of Life Sciences, Department of International Environment and Development Studies.

Tahmased A, Ehlers E, Schetter C, 2013. Climate change and mountain pastoralism. The Shahseven of Northern Iran. Erkunde, 67(4): 309-323.

Thornton P K, Van de Steeg J, Notenbaert A et al., 2009. The impacts of climate change on livestock and livestock systems in developing countries: A review of what we know and what we need to know. Agricultural Systems, 101(3): 113-127.

Thornton P K, Kruska R L, Henninger N et al., 2002. Mapping Poverty and Livestock in the Developing World. International Livestock Research Institute, Nairobi, Kenya. 124 pp.

Undeland A, 2005. Kyrgyz Republic: Livestock Sector Review: Embracing New Challenges. Europe and Central Asia Region, Environmentally and Socially Sustainable Development. Washington, DC: World Bank

Wallner A, Bauer N, Hunziker M, 2007. Perceptions and evaluations of biosphere reserves by local residents in Switzerland and Ukraine. Landscape and Urban Planning, 83: 104-114.

Wangui E E, 2008. Development interventions, changing livelihoods, and the making of female Maasai pastoralists. Agriculture and Human Values, 25(3): 365-378.

Westreicher C A, Mérega J L, Palmili G, 2007. The economics of pastoralism: Study on current practices in South America. Nomadic Peoples, 11(2): 87-105.

Wiley L A, 2004. Looking for peace on the pastures: Rural land relations in Afghanistan. Synthesis Paper Series. Afghanistan Research and Evaluation Unit: Kabul.

Wu N Richard C E, 1999. The privatisation process of rangeland and its impacts on the pastoral dynamics in the Hindu Kush Himalaya: The case of Western Sichuan, China. In: People and Rangelands. Proceedings of VI International Rangelands Congress, Townsville, Australia, 14-21.

Wu N, Ismail M, Joshi S et al., 2014. Livelihood diversification as an adaptation approach to change in the pastoral Hindu-Kush Himalayan Region. Journal of Mountain Sciences, 11(5): 1342-1355.

Young J, 2012. The Fate of Sudan: The Origins and Consequences of a Flawed Peace Process. London.

Zinsstag J, Ould Taleb M, Craig P S, 2006. Editorial: Health of nomadic pastoralists: New approaches towards equity effectiveness. Tropical Medicine \& International Health, 11(5): 565-568. 